DOI: https://doi.org/10.34069/AI/2022.49.01.30

How to Cite:

Mostova, I., Yanyna-Ledovska, Y., \& Semenova, N. (2022). An analysis of a choreographic work: fundamental and innovative methodology. Amazonia Investiga, 11(49), 277-284. https://doi.org/10.34069/AI/2022.49.01.30

\title{
An analysis of a choreographic work: fundamental and innovative methodology
}

\section{Аналіз хореографічного твору: фундаментальна та інноваційна методологія}

Received: November 1, 2021

Accepted: January 12, 2022

\section{Abstract}

The article analyzes the methodology of professional critical analysis of dance art work and outlines the prospects of development of this vector of choreological activities. The purpose of the article is a goal-oriented description of methods of professional analysis of choreographic works in the context of habit training of choreographers' critical thinking. The methods used are as follows: method of synthesis, systematic approach, method of structural analysis, method of analysis of musical content, analysis of the specific character of audience perception, analysis of semiotic components of the work, analysis of the dialectic of a choreographic text. The criteria for the analysis of choreographic works can be worked out through the use of innovative technologies. it is possible to make additional arguments based on the experience of mathematical, music and linguistic methodology. The combination of innovative technologies with techniques that consider the quantitative and qualitative indicators of dance, allows the analysis of a choreographic work to move to a new more evidence-based level. Further development of this applied research issue can be aimed at improving the theoretical apparatus of the proposed innovative methods, or the development of new techniques based on technical developments in the field of GPSdevices.

\begin{abstract}
Анотація
У статті проаналізовано методику професійного критичного аналізу танцювального мистецтва та окреслено перспективи розвитку даного вектора хореологічної діяльності. Метою статті $\epsilon$ цілеспрямований опис методів професійного аналізу хореографічних творів у контексті тренування критичного мислення хореографів. Використовуються такі методи: метод синтезу, системний підхід, метод структурного аналізу, метод аналізу музичного змісту, аналіз специфіки сприйняття аудиторії, аналіз семіотичних компонентів твору, аналіз діалектики хореографічного твору. текст. Критерії аналізу хореографічних творів можуть бути розроблені шляхом використання інноваційних технологій. можна наводити додаткові аргументи, спираючись на досвід математичної, музичної та лінгвістичної методики. Поєднання інноваційних технологій 3 техніками, що враховують кількісні та якісні показники танцю, дозволяє аналізу хореографічного твору перейти на новий, більш доказовий рівень. Подальша розробка даного питання прикладного дослідження може бути спрямована на вдосконалення теоретичного апарату пропонованих інноваційних методів, або на розробку нових методик на основі технічних розробок у галузі GPS-пристроїв.
\end{abstract}

\footnotetext{
${ }^{119}$ Kharkiv State Academy of Cultural, Kharkiv, Ukraine.

${ }^{120}$ Kharkiv State Academy of Cultural, Kharkiv, Ukraine.

${ }^{121}$ Kharkiv State Academy of Cultural, Kharkiv, Ukraine.
} 
Keywords: methods of choreographic analysis, choreographic work, critical activity, choreography.

\section{Introduction}

The training of professional choreographers is based on understanding the range of general and special competencies that form the final list of necessary skills. The list of professional disciplines offered for the study is aimed, inter alia, at mastering the ability of artistic and critical activities in the field of choreography. One of the areas of artistic and critical activities is the professional analysis of a choreographic work, which contributes to the development of choreographic art in general, improving choreography skills, the habit training of professional critical activity. The problem of development of this vector of choreographer's activity is the lack of conceptualized methods of dance analysis. An objective analysis of a choreographic work still remains a discursive theme, due to many particulate factors. The present study collects the most relevant methods of analysis of a choreographic work, which were developed in different historical periods of the foundation of this field of study and make a competent analysis possible, excluding subjective evaluations. It is through the conceptualization of convergent methods of professional comprehension of a choreographic work that it seems possible for future choreographers to acquire special competencies.

The purpose of the article is a goal-oriented description of methods of professional analysis of choreographic works in the context of habit training of choreographers' critical thinking.

\section{Theoretical Framework or Literature Review}

Defining "dance" as a cultural model, which was presented by V. V. Romm in his research "Dance as a Factor in the Evolution of Human Culture" enabled to consider dance as a symbol-code in a complex system of cultural signs, expanding the methodology of dancological research (Romm, 2006).

The analysis of a choreographic work in the modern system of values, as well as due to the significant development of forms of performance, is greatly complicated by moving away from the standard interaction of a choreographer, performer and spectator. The given three-phasal nature is reflected in the analysis of dance. Jacqueline M. Smith-Autard in
Ключові слова: методи хореографічного аналізу, хореографічна робота, критична діяльність, хореографія.

the monograph "Dance Composition: a Practical Guide to Creative Success in Dance Making", considering important aspects and stages of dance creation, substantiates the specific character of its analysis and highlights the basic principles of creating a perfect dance: knowledge of the structural elements of dance, mastering the methods of composition of a form, feeling and style conception - the author motivates to analyze these components in understanding the choreographic style (Smith-Autard, 2010). The practical guide to the creation of dance also reveals the problems of creating a motive, the interaction of idea and style, analysis of the semantics of movement, stage interpretation of the daily life movement and many others. "Dance Composition Basics: Capturing the Choreographer's Craft. First Edition" developed by Pamela Anderson Sofras introduces the mechanics of creating a dance as exemplified in analyzing the work of two outstanding choreographers. Describing the main stages of development and the creation of dance, the author uses the structural method of analysis of a choreographic work, thus revealing the special aspects of the use of this method (Anderson Sofras, 2006). Katherine Flatt in "Choreography: Creating and Developing Dance for Performance" also focuses on the analysis of the components of dance. The author explores the process of an idea creation, the formation of the context of movement, the geometry of stage space and the importance of its understanding in creating a dance, the structure of movement in time and space, the mechanics of working with music, the structure of forms and others (Flatt, 2020). Thus, Katherine Flatt highlights the key aspects in the process of dance analysis, regardless of the chosen technique. Considerable attention to dance is given in the author's work "The Skill of the Choreographer in Modern Dance" by V. Yu. Nikitin. V. Yu. Nikitin formulates the purpose of a competent dance analysis, identifies the main components that need to be analyzed, and asks the concise questions, the answers to which characterize the dance (Nikitin, 2020). The author also adheres to the principles of the method of structural analysis of a choreographic work, which in his opinion is the most appropriate in the study of dance at different levels of professionalism. 


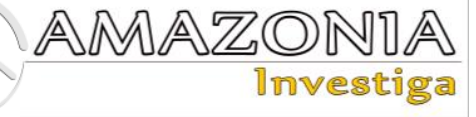

It is important to note that this scientific work is aimed at conceptualizing the methods of critical analysis of dance, developed by a particular choreographer and embodied by performers. In this case, the analysis of the "creativity" of dancers is not taken into account, considering them as replicators. Therefore, the use of the proposed Lucie Clements' Method of Consensual Assessment Technique (CAT) has not been the case here (Clements, 2018), because this method is aimed at analyzing situational creativity.

\section{Methodology}

In the case of professional analysis of a choreographic work, it is recommended to use the methods that consider the object as a holistic cultural phenomenon (method of synthesis, systematic approach and other general scientific methods), as well as the methods aimed at determining the special aspects of individual components of a choreographic work (method of structural analysis, method of analysis of musical content, analysis of the specific character of audience perception, analysis of semiotic components of the work, analysis of the dialectic of a choreographic text, etc.). This approach enables to assess dance as a cultural and artistic phenomenon from many perspectives, taking into account the peculiar features of types, genres, forms and styles of dance. The outlined methods are the most common among professional critics of choreographic art, choreographers, practitioners and teachers. Specialists in the context of dance evaluation during competitions and festivals are most often involved in this methodology.

The range of dancological methods today varies from general culturological to choreological. For the purposes of studying dance analysis methods, a systematic approach was involved, combined with semiotic analysis as a basis for understanding dance as a system, and the formation of a three-phase principle in professional critical methodology. By incorporating a systematic approach, it has been possible to consider the coordinated functioning of all the subsystems of a choreographic work, formulating the concept of further development of dance analysis methods. In addition, the article describes such methods as structural analysis, analysis of musical content, analysis of the specific character of audience perception, analysis of semiotic components of a work, analysis of the dialectic of a choreographic text, quantitative analysis of musical and choreographic score - as a basic methodology of dance analysis. An important science-based step was the formulation of the latest dance methodology - the method of analysis of emotional harmonics, the method of studying dance using Viperpod.

\section{Results and Discussion}

Mastering the profession of a choreographer in the field of modern education is based on three main principles: mastering the skills of dance creation, performance and analysis. These three principles have become fundamental and require deepening the theoretical basis for a professional analysis of a choreographic work. The theoretical study of dance has made significant strides from its inception to the use of modern computer programs. A dance conception not only as a rhythmic movement or emotional manifestation has led to the constant improvement of approaches to its analysis. In understanding these three principles of the choreographer's profession, it is important to comprehend "dance" as a form of human existence in time, space, circumstances and regulations.

The purpose of any analysis of a choreographic work is the need to define dance as a subject of certain data relay, the role of dance in sociocultural changes of a particular country or epoch, recognition of dance as an artistic pattern in a certain artistic period (without making a subjective evaluation), as well as highlighting the features of the choreographer's style or the style of the whole choreography school.

At the beginning of the analysis of the work it is necessary to determine the main approach to this process. It can be built based on the previously mentioned three-phasal nature of dance as a cultural phenomenon: analysis of dance in terms of its creation (analysis of the structure of dance), in terms of the mechanics of its performance (analysis of the impact of performing skills and personality of the performer, time and space) and from the standpoint of its audience perception.

At the beginning of the analysis it is possible to determine the general features of dance, which are outlined in the feasibility of determining the idea of the work, its clarity and the characteristic aspects of its development during a choreographic work; definition of style, features of its formation and canonicity; identifying the logic structure of the work. Using the method of structural analysis, the critic must determine the idea and form of dance (their interaction, interdependence), and outline the type to which the choreographic work belongs. The idea of 
dance or image (emotional state) is always present and becomes the main goal of the author, which s/he pursues with reference to the creative process (Kolnoguzenko and Mostova, 2019). An idea or emotion is embodied in a form characterized by a set of certain structural components. It is the form during the demonstration of a choreographic work that will be appreciated by the spectator and through its aesthetic perception s/he will comprehend the idea or emotional component (choreographic image).

At the next stage, it is requisite to focus on the analysis of the features of the form: determine the specific features of the structure of horizontal dance drama (comprehension of the signs of the build-up, introduction, development of action, culmination and denouement of dance, combining these parts into a single whole, the duration of these components), identify the structure of screenwriting, characterization of artistic and choreographic images, the interaction of screenwriting, horizontal and musical drama. The conclusions obtained at this stage of the analysis should be correlated with certain styles and ideas of dance, which directly emphasizes the relationship of these components. In the scope of the analysis of the form it is appropriate to determine the features of the author's use of specific techniques for structuring a spatial composition (increasing, contrast, still frame, polyphony, etc.): the relevance of their use, interaction with musical drama, the impact on the development of choreographic images.

Dividing the composition into the main components, it is essential to proceed to the next phase of a structural analysis: studying the features of dance movement (dialectics of dance language) and the organization of performers on stage or any other space (analysis of stable patterns, spatial movements). For many centuries, dance has been understood as a cultural phenomenon in which historical, social and cultural information is stored and relayed in specific symbols-codes. The direct bearer of a cultural text is a dance movement that is formed (like any other text) based on a certain context. That is, dance is able to endow culture with a certain form and make the cultural meanings of a certain epoch more objective. The flexibility and stretching language relays kinetic, contact, psychological, pragmatic information, and as part of its research, it is important to return from the choreographic text to its context in order to better understand the idea of dance. The movement is born from the very life of a human being and it is the natural movement that becomes the basis of dance: in folk dance, the natural movement is characterized by ethnicity, in modern dance it reproduces a certain emotion and is born from an instant state, in the ballroom dance it embodies the nature of culture or era, the gender-sensitive interaction, ethics and aesthetics of relationships. Certainly, the author carries out considerable professional work before the movement becomes part of the dance. The symptomatic pattern of human behavior embodied in the movement requires choreographic improvement, expansion, dramatic and choreographic hyperbole, academicization (depending on the type of dance and stage necessity). The analysis of the movement, as a dance component, is formed by determining the nature of the movement, its interaction with musical drama, the conformity of the movements of the idea and style of dance, the reconciliation of dance with dynamic and static movements, the consonance between dance movements and patterns, features of the movement development in different parts of the horizontal drama of the work. The analysis also needs to determine how the choreographerauthor used the potential for developmental movement, with which elements the choreographer complicated the movements and created options for them (Smith-Autard, 2010). The analysis of a dance pattern also takes into account its development in different parts of dance drama. It is also required to determine whether the patterns were interconnected, whether they developed from simple to complex, identify the mechanics of the interaction of pattern and movement, outline exactly how the author of the dance work uses the stage space, distributes the performers, shifts the attention from the mass of performers to the soloists, whether he uses the shift of the point of perception (whether the choreographer uses this technique rationally). The critic must analyze the relationship of patterns in dance with the idea, images and dance style. The presence and specific features of the creation of the motive need special attention in the process of the analysis of dance movements and patterns, as components of the dance composition. According to Jacqueline M. Smith-Autard, the main motive is a dance phrase, which is formed from the movements (or movement) given at the beginning of the composition and is artistically evaluated and improved by the author (Smith-Autard, 2010). Thereafter, the original motive is developed, varied and clarified by the author, by means of improvisation and use of accumulated performing experience. According to the lexical origin, the motive is a theme or subject that especially dominates in the 


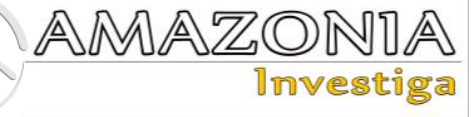

composition of the work of art. Glossaries also interpret the term "motive" as the main theme or idea of the work; a certain artistic sample, a characteristic feature of the work. In a choreographic work the motive can be expressed in movement, pattern, compositional detail, compositional fragment, props, moving scenery that becomes part of the composition. Analyzing the motive as a component of the work and an indicator of its features, it is indispensable to take into account the relevance of the motive, style and idea of the work, how often the motive is relayed or duplicated, by what expressive means the motive develops in time and space, whether the development of the motive is correlated with the development of horizontal and vertical drama, whether the motive is obvious to the viewer or recognizable at the level of inner feeling, whether the motive is embodied by all performers or affirmed in the choreographic score of the soloist.

An integral part of the structural analysis of dance is the study of the impact of performance features on the formation of the work. Paying attention to this aspect of the choreographic work, it is appropriate to determine the influence of performing skills on the embodiment of the idea and choreographic images, outline how the technical abilities of the performers influenced the perception of the dance by the audience (improved or worsened).

Consistently, it is indispensable to analyze the work from the point of view of the perceptual style of the audience. It is important to understand how the viewer perceives the information encoded in the symbols, whether the semantics of the symbols and images are reflected in the viewer's worldview. It is also significant to analyze the psychological influence of external factors on the process of awareness of a choreographic work. Such factors include: the properties of the stage space, the saturation of the choreographic work with information, personal qualities of the viewer and his/her previous experience.

In addition, it is meaningful to analyze additional expressive means, such as musical accompaniment, dance stage design, costumes. Thus, structural analysis covers almost all the components of a choreographic work, gives the opportunity to identify specific features at a sufficient level, as well as to create an idea of the choreographer's style. However, this method is not devoid of subjective evaluations and interpretations, as most of the conclusions are based on the experience of the critic. In this case, there is a need to form a methodological basis for choreological research, based on the objective quantitative indicators.

Keeping in mind a rapid process of digitalization of all spheres of human life, it is important to predict the development of dancological methodology and offer innovative means of dance analysis.

Choreology, as a relatively young science, shaping the methodological apparatus is based on identical developments in the related fields. Against the background of this thesis, the need for the formation of special methods for the study of dance and movement is increasingly outlined in scientific practice, taking into account innovative technologies. The lack of purely choreological methods of dance analysis can be filled by turning to the methodological practice of linguists or musicologists. The compensation for the lack of dancological methods, due to the appeal to the methodology of these scientific fields, is caused by the morphological affinity of dance, music and words.

Recently, the scientific community was offered to use the method of quantitative analysis of a choreographic work. This method is based on the mathematical quantitative analysis and quantitative analysis of a linguistic work. Despite a certain formality and fragmentation in the approach to the study of the object, this method as objectively as possible estimates quantitative indicators, and also relies only on factual data in the study. Shifting attention to the analysis of the dance opus by means of quantitative analysis, the significant objectivity is emphasized in obtaining the final results of the research process, which excludes the subjective interpretation of a choreographic work by the critic and the use of the terms "like", "dislike" (Mostova, 2019). Before using in dance studies (dancology), the method of quantitative analysis has been used in musicology: the researcher developed the formula of "musical foot" (a fragment of the metrorhythmic construction of a musical phrase), which was further analyzed on the principle of alternating short and long "syllables", enabling to determine the belonging to a particular form or musical archetype. In linguistics, this method is involved in the quantification of language units. In the realm of the study of a choreographic opus, the quantitative analysis is used as a means of studying the structure of dance, and is relevant for the analysis of minimal movement or any form of a dance work. 
The method of quantitative analysis of a choreographic opus was developed and proposed by N. Sargsyan. The principles of its application in the analysis of classical dance forms are presented in her scientific articles "The Quantitative Method of Analysis of Choreographic and Musical Elements (the Case of Music and Kinetographic Scores of Stoyan Djoudjeff and S. S. Lisitsian)" (Sargsyan, 2016), "Methods of Analysis of Choreographic Opus Using Terms Applied in Musicology" (Sargsyan, 2015). The method proposed by N. Sargsyan is not possible without the use of a dance recording system. In her research, the author turned to recorded choreographic scores by the method of the Armenian choreologist S. S. Lisitsian (the system of recording dance is described in the monograph "Kinetography (recording movement)" (Lisitsian, 1940) and the Bulgarian musicologist Stoyan Djoudjeff (the dance recording system is described in the monograph "Bulgarian Folk Choreography" (Djoudjeff, 1945). Thus, the disadvantages of this method include the need for parallel development of musical and choreographic scores, as well as their further comparison, which requires basic knowledge of music literacy and solfeggio from choreographers.

Thus, the application of the method of quantitative analysis of choreographic score is based on its comparison with the musical score and the feature analysis of the sequence of choreographic movements. During the analysis of a fixed musical and motor recording, the formula of the sequence of movements, the socalled "dance foot", is derived, which is subject to direct further analysis. The choreographic foot is derived by the method of calculating the ratio and sequence of short and long syllablesmovements that coincide with the musical foot. Fixed music and choreographic material makes it almost impossible to add a critic's subjective vision to an analysis based on his or her worldview or life experience. The formulated choreographic foot captures quantitative and qualitative indicators of movement with mathematical accuracy, and the use of the most advanced systems for recording movements allows characterizing movement from the standpoint of its performance in time and space and determining its amplitude.

An important stage in preparing for the quantitative analysis of a choreographic work is the process of creating a dance recording based on the use of sign systems. All the sign systems that have been formed today are included in the so-called "descriptive" group on the principle of displaying a choreographic text. For the quantitative method of analysis, the systems for fixing a choreographic work of a "descriptive" group are suitable. But the increased criticism of the "visual" group of ways of fixing dances, which was relevant in the middle of the twentieth century, does not reflect the actual situation.

Nowadays the expansion of video recording opportunities of a choreographic movement and choreographic work has reached a new technical level. Related to this is the development of an innovative methodology for analyzing a choreographic work. Video gadgets make it possible to see a movement or composition from multiple shots and angles at once, to fix the area of resistance of a dancer during the performance of the movement, the direction of displacement of body weight, the movement of several dancers simultaneously with a significant clarity of the movement compilation, without learning the speed of its performance. In addition, when analyzing the movement of dancers, as well as the analysis of choreographic work, modern GPS-devices can be used. These are standalone Internet devices that are designed to perform a specific function and do not require connection to an additional device; they are actively used in sports to fix the strength and amplitude of the dance movement, acceleration of the dancer, his physical activity. Such devices today include Viperpod, developed by STATSports to account for the physical performance of football players. Thus, video motion capture must be used with the addition of the latest technology. However, for the sake of clarity, the data collected by technical devices need further decryption and presentation in the form of recorded data. Therefore, for some convenience, the descriptive method of fixing the dance is immediately used in the quantitative analysis. Improving the quantitative analysis through the introduction of digital technologies will make the results more objective and will accept the results of the choreological analysis as factual information.

Due to the active development of software in various fields of art, the process of creating kinetograms (choreographic scores) is simplified. European computer software developers began to improve their computer software data in 1987, when it became necessary to simplify and speed up the process of creating a dance recording. At the beginning of the foundation of intellectual development in this field, three programs were patented that accelerated the drawing of kinetograms, transferring them from paper to digital. The programs had certain shortcomings that needed 


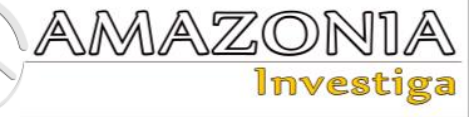

to be eliminated as soon as possible: the program interface was inconvenient and difficult to use, it was impossible to add new characters, only two programs ran on the Microsoft Windows operating system. Over the years, the software has been improved, meeting the current needs of authors in the accelerated fixation of complex choreographic works. The latest LabaNotator program 1.7.0. (Labanotation graphics edition) is based on the Microsoft Windows operating system; it makes it possible to edit existing and add new characters, create multiple layers of characters that can then be separated, moved and conveniently edited; the program has a multilingual interface (English, German, Croatian, Slovenian). The theoretical part of the program was developed on the basis of R. Laban's dance recording system (PrestonDanlop, 2002). The Macintosh operating system also has a fairly advanced program, based on the theoretical developments of R. Laban, LabanWriter 4.7.2. The program has more than 700 characters, has a differentiation of body parts, indications of movement directions, levels and types of movements, as well as the ways to indicate their duration.

Due to the use of innovative intellectual programs and the use of the method of quantitative analysis, it is possible to conceptualize the author's style during the analysis of a choreographic work, confirmation of the dance affiliation to the type, genre, style and certain form, an analysis of the correspondence of the dramaturgy of a choreographic work to the dramaturgy of music (Mostova, 2019).

Innovative computer technologies can also be applied in the case of studying the emotional component of a choreographic work: the socalled method of emotional harmonics analysis (harmonic - an elementary component of a complex harmonic oscillation). This method was used within the framework of studying the emotional arches of literary works. The theory of emotional arches was first proposed in 1995 by Kurt Vonnegut, who graphically depicted the development of the emotional component of literary plots. According to his idea, all the plots develop within the framework of graphic schemes, which are not as many as it seemed at the time. Kurt Vonnegut's research initiated the development of mathematical study of the emotional component of a literary work. To date, discussions have continued over the number of emotional transitions, but thanks to the work of Andrew Reagan and scientists at the University of Vermont Computing Storyboard Laboratory in
Burlington, it was possible to create schemes of emotional arches and determine the most common of them by the method of intellectual analysis. The essence of the method was to determine the impulse of words, which allowed forming a graphic scheme. The method of analysis of emotional harmonics can be used in the study of various types, forms and styles of dance. Given the concept that dance is a text that reproduces a certain context and relays the information, as well as reconstructs reality through emotional impact, influencing the viewer's consciousness, it becomes possible to analyze the emotional expressiveness of movement as a code. Transmission and recording the frequency of impulses of dance movements in the work, which is possible through the use of modern technologies, allows creating emotional arches that reconstruct the idea of a choreographic work in the graphic plane. Further analysis of a choreographic work from the standpoint of the emotional structure of the dance will allow specifying the patterns based on objective data, according to which some dances are gaining popularity among the audience, while others are ignored.

\section{Conclusions}

Summing up, it should be noted that the criteria for the analysis of choreographic works, having been developed over time by the prominent dance theorists and practitioners of choreographic art, can be worked out through the use of innovative technologies. Given the developed methods of analysis of the work, which have already become fundamental, it is possible to make additional arguments based on the experience of mathematical, music and linguistic methodology. The combination of innovative technologies with techniques that take into account the quantitative and qualitative indicators of dance, allows the analysis of a choreographic work to move to a new more evidence-based level.

Further development of this applied research issue can be aimed at improving the theoretical apparatus of the proposed innovative methods, or the development of new techniques based on technical developments in the field of GPSdevices. The findings can be applied in the practical activities of choreographers, teachers of professional disciplines, critics of choreographic art. 


\section{Bibliographic references}

Anderson Sofras, P. (2006). Dance Composition Basics: Capturing the Choreographer's Craft. First Edition. Champaign, IL: Human Kinetics.

Clements, L., Redding, E., Sell, Nl., \& May, J. (2018). Expertise in evaluating choreographic creativity: an online variation of the consensual assessment technique. Frontiers in Psychology, Vol. 9, 1-8.

Djoudjeff, S. (1945). Bulgarian folk choreography. There are many examples of the Macedonian folklore. Sofia: Ministry of Public Enlightenment. Retrieved from: https://knigolubie.com/index.php?id_product $=10999 \&$ controller $=$ product

Flatt, K. (2020). Choreography: Creating and Developing Dance for Performance. Ramsbury: The Crowood Press.

Kolnoguzenko, B. \& Mostova, I. (2019). The art of choreographer: lecture notes for student. Kharkiv: KhSAC. Retrieved from: http://195.20.96.242:5028/khkdakxmlui/handle/123456789/1088

Lisitsian, S. S. (1940). Kinetography (recording movement). Moscow: Art [Iskusstvo]. Retrieved from: https://search.rsl.ru/ru/record/01005220255

Mostova, I. (2019). The experience of ethnochoreology in understanding the stylistics of slobozhansky dance folklore.
Dance studios [Tantsiuvalni studii], 2(1), 49-58.

Nikitin, V. Yu. (2020). The choreographer's skill in modern dance. St. Petersburg: Lan', Planet of music.

Preston-Danlop, V., \& Sanchez-Colberg, A. (2002). Dance and the performative. A choreological perspective - Laban and beyond. London: Verve publishing.

Romm, V. V. (2006). Dance as a Factor in the Evolution of Human Culture. (Phd thesis) Novosibirsk State Conservatory (Academy), Russia. Retrieved from: https://newdisser.ru/_avtoreferats/01003308059.pdf

Sargsyan, N. G. (2015). Methods of analysis of choreographic opus using terms applied in musicology. Kantekh, 4(65), 236-248. Retrieved from: https://arar.sci.am/dlibra/publication/184017

Sargsyan, N. G. (2016). The quantitative method of analysis of choreographic and musical elements (the case of music and kinetographic scores of Stoyan Djoudjeff and S. S. Lisitsian). Scientific Notes of the Gnessin Russian Academy of Music [Uchenye zapiski Rossijskoj akademii muzyki imeni Gnesinykh], 1(16), 13-21. Retrieved from: https://uz.gnesinacademy.ru/wpcontent/uploads/archive/2016/release16.pdf

Smith-Autard, J. (2010). Dance Composition: A practical guide to creative success in dance making. New York: Methuen Drama. 